Ivanova Tatyana Yurievna ${ }^{1}$

Kochkova Yana Anatolyevna ${ }^{2}$

Ulyanovsk state university,

Faculty of management in Ulyanovsk, Russia

Snežana Živković ${ }^{3}$

University of Niš, Faculty of occupational safety in Niš, Serbia
ORIGINAL SCIENTIFIC ARTICLE

DOI:10.5937/ekonomika1703013Y

Received: May, 26, 2017

Accepted: Jun, 15, 2017

\title{
MARKETING ACTIVITY PERFORMANCE: VALUATION PROBLEM AND ITS RESOLUTION
}

\begin{abstract}
At present time there is no facility that normally exists without a marketing division. Relevance of the marketing even rises day by day. Marketing budgets tend to the substantial growth over the last 15 years. Issues related to the grounding of the cost escalation remain open. This situation creates tensions in relations between financial and marketing departments. To improve the marketing activity and to increase the marketability facilities need regularly measure the performance of the marketing.
\end{abstract}

Key words: marketing perfomance; efficiency; evaluation methods; risks

JEL classification: M31

\section{ПЕРФОРМАНСЕ МАРКЕТИНШКИХ АКТИВНОСТИ: ПРОБЛЕМ ПРОЦЕНЕ И ЊЕГОВО РАЗРЕШЕЊЕ}

\begin{abstract}
Апстракт
У садашњости нема установе која нормално постоји без одељења маркетинга. Значај маркетинга чак расте из дана у дан. Буиети маркетинга бележе значајан раст у последњих 15 година. Теме које се односе на смањење пораста трошкова остају отворене. Ова ситуација ствара тензије у односу између одељења финансија и марткетинга. Да би се побољшале маркетиншке активности и да би се повећала успешност продаје, установе требају да редовно мере перформансе маркетинга.
\end{abstract}

Кључне речи: перформансе маркетинга; ефикасност; методе процене; ризиции

\footnotetext{
${ }^{1}$ tivanova.j@gmail.com

${ }^{2}$ koc345@yandex.ru

${ }^{3}$ snezana.zivkovic@znrfak.ni.ac.rs 


\section{Introduction}

Necessity in the complex analysis of the marketing activity is caused by the management's necessity in making of right managerial solutions, its state and condition at the facility and improvement opportunities.

There is no generalized point of view in the sphere of the performance measure of the marketing activity. The majority of methods come to the cost analysis or the examination of separate functions. If we run the analysis of such indices as the sales volume or the profitability and associate them with the marketing cost, we will be able to see the overall performance of the company. It is very complicated and almost impossible to detach the marketing share. This analysis does not guarantee the reliability of data received because the company success can be connected with not only marketing measures run but also with some external favorable conditions. Moiseeva and Konysheva (2002) suggest determining the performance taking into consideration several functions: market research, assortment and sales policy, communications. These scientists closer approached to the development of the marketing performance calculation method. But they did not achieve the practical application because scales for the qualitative measure of the marketing and the calculation model of the aggregate performance indicator were not developed.

Besfamilnaya and Rozhkov (2002) suggests using an express measure of the marketing taking into consideration the series of indices (market scale, sales, marketing expenses, orders and competition). In this method there is subjectivity in the determination of the importance of indices and in the determination of measures. It is also should be noted that the measure scale is narrow (only 3 values are possible: -1 ; 0 ; +1 ). Moreover, the number of indices measured is not enough (there are only 5). Many authors (Assel, 1999; Ambler et al., 2001; Kaplan \& Norton, 2001; Ward, 2004; Starov \& Alkanova, 2010) adhered to the application of economic and mathematical methods. However, the performance measure of the marketing activity (Ambler \& Kokkinaki, 1997; Appiah-Adu, 1998; Doyle \& Wong, 1998; Ambler, 2000; Appiah-Adu et al., 2001; Woodburn, 2004; Eusebio et al. 2006) is carried out taking into consideration only separate categories (advertising, expenses and etc.). Till present there is no method of the complex analysis of the marketing service which could include economic, mathematical, statistical and other quantitative and qualitative methods. That's why in this article we suggest our vision of the marketing performance measure at the modern facility.

\section{Method}

Concerning the concept of the marketing activity performance it could be said that this concept can be divided into 2 items: internal and external performance.

Internal performance we understand as a set of control functions which adequate implementation can improve the performance of the marketing department. In recent times concerning the performance measure of the company activity we measure subdivisions head activity i.e. the management which ensures the smooth functioning of the facility control system. Management (control) system function is to foresee consequences, plan 
objectives, organize the process, manage resources, coordinate actions and control the task performance.

External marketing performance is a complex of functional obligations of employees of the marketing department which implementation influences the sales boost of the company product and the increase of its market value. It is the marketing functions fulfillment such as advertising development, marketing researches, product promotion and etc.

Combination of internal and external performance forms a general performance. But how it could be measured? Firstly, it is necessary to determine indices which should be measured. Indices analyzed please refer to Fig.1.



Fig.1 Effectiveness of marketing activities

Source: Own source

Our method consists of four parts:

1. Internal efficiency determination;

2. External efficiency determination;

3. Risk identification; degree of importance in decision-making;

4. Analysis of results and recommendations.

To transform qualitative measures to quantitative ones we suggest using the following scale:

1. complete correspondence with the measure method criterion $-\langle 5 »$;

2. incomplete correspondence $-\ll 4 »$;

3. partial correspondence $-\ll 3 »$;

4. complete lack of correspondence $-\ll 2 »$.

5. Activity is not carried out $-\ll 1 »$.

Indicators of internal efficiency are presented in Table 1. 
Table 1 An evaluation of internal marketing efficiency

\begin{tabular}{|c|c|c|c|c|}
\hline № & \begin{tabular}{|l} 
Evaluation \\
Parameters
\end{tabular} & Description & Evaluation method & Scale \\
\hline & \multicolumn{4}{|l|}{ Planning } \\
\hline 1 & Goal setting & $\begin{array}{l}\text { Goals should be SMART - specific; } \\
\text { - measurable; } \\
\text { - agreed upon; } \\
\text { - realistic; } \\
\text { - time - based. }\end{array}$ & $\begin{array}{l}\text { The analysis of } \\
\text { documentation }\end{array}$ & $\begin{array}{l}1 \text { point: Bad goal } \\
\text { setting; } \\
2 \text { points: More } \\
\text { than } 5 \\
\text { discrepancies; } \\
\mathbf{3} \text { points: } 3-4 \\
\text { discrepancies; } \\
\mathbf{4} \text { points: } 1-2 \\
\text { discrepancies; } \\
\mathbf{5} \text { points: All documents } \\
\text { meet the criteria }\end{array}$ \\
\hline & \multicolumn{4}{|l|}{ Organizing } \\
\hline 2 & $\begin{array}{l}\text { Degree of } \\
\text { formalization }\end{array}$ & $\begin{array}{l}\text { Formalized structures are those in which there } \\
\text { are many written rules and regulations. These } \\
\text { structures control employee behavior using } \\
\text { written rules, so that employees have little } \\
\text { autonomy to decide on a case-by-case basis. } \\
\text { An advantage of formalization is that it makes } \\
\text { employee behavior more predictable. }\end{array}$ & $\begin{array}{l}\text { The analysis } \\
\text { of company } \\
\text { documentation } \\
\text { (job description; } \\
\text { regulations } \\
\text { for marketing } \\
\text { department) }\end{array}$ & $\begin{array}{l}\text { 1p: Completely untrue; } \\
\text { 2p: More than } 5 \\
\text { discrepancies; } \\
\text { 3p: } 3-4 \\
\text { discrepancies; } \\
\text { 4p: Less than } 2 \\
\text { discrepancies; } \\
\text { 5p: Totally } \\
\text { coincides }\end{array}$ \\
\hline 3 & $\begin{array}{l}\text { Number of } \\
\text { subordinates }\end{array}$ & $\begin{array}{l}\text { A manager's span of control is the number of } \\
\text { employees that he or she can effectively be in } \\
\text { control of at any one time. In direct submission } \\
\text { should be no more than } 7+/-2 \text { people. }\end{array}$ & $\begin{array}{l}\text { Interview with the } \\
\text { head of the marketing } \\
\text { department }\end{array}$ & $\begin{array}{l}\text { 1p: It is absolutely } \\
\text { impossible to manage; } \\
\text { 2p: Low; } \\
\text { 3p: Normal; } \\
\text { 4p: Above average; } \\
\text { 5p: High rate } \\
\text { of controllability }\end{array}$ \\
\hline 4 & $\begin{array}{l}\text { The } \\
\text { availability } \\
\text { of specialized } \\
\text { software and } \\
\text { devices }\end{array}$ & $\begin{array}{l}\text { One of the main tasks of the organization is } \\
\text { to provide jobs with technical devices. In the } \\
\text { context of computer technology, a device is } \\
\text { a unit of hardware, outside or inside the case } \\
\text { or housing for the essential computer. When } \\
\text { the term is used generally (as in computer } \\
\text { devices ), it can include keyboards, mouses, } \\
\text { display monitors, hard disk drives, printers, } \\
\text { audio speakers and microphones, and other } \\
\text { hardware units, software (1C;CorelDraw, } \\
\text { Photoshop and etc.) }\end{array}$ & $\begin{array}{l}\text { Workplace } \\
\text { observation }\end{array}$ & $\begin{array}{l}\text { 1p: Department } \\
\text { is not fully } \\
\text { provided } \\
\text { with technical } \\
\text { devices and programs; } \\
\text { 2p: More than } \\
3 \text { discrepancies; } \\
\text { 3p: } 3 \text {-4 discrepancies } \\
\text { 4p: } 1 \text { discrepancy; } \\
\text { 5p: Fully provided }\end{array}$ \\
\hline 5 & $\begin{array}{l}\text { Personnel } \\
\text { development }\end{array}$ & $\begin{array}{l}\text { Highly trained and motivated staff is } \\
\text { essential for achieving good results. } \\
\text { While offering employees support and } \\
\text { encouragement is a manager's primary } \\
\text { task, employees themselves must } \\
\text { take responsibility for their personal } \\
\text { qualifications and self-development. }\end{array}$ & $\begin{array}{l}\text { The analysis of } \\
\text { documentation }\end{array}$ & $\begin{array}{l}\text { 1p: Low qualification } \\
\text { for the entire marketing } \\
\text { department } \\
(0-10 \%) \\
\text { 2p: }(10-20 \%) \\
\text { 3p: } 30-50 \% \\
\text { 4p: } 50-70 \% \\
\text { 5p: All employees } \\
\text { are highly } \\
\text { qualified }(100 \%)\end{array}$ \\
\hline & \multicolumn{4}{|l|}{ Motivation } \\
\hline
\end{tabular}




\begin{tabular}{|c|c|c|c|c|}
\hline 6 & $\begin{array}{l}\text { Good } \\
\text { motivation } \\
\text { system }\end{array}$ & $\begin{array}{l}\text { Knowing how and why to motivate } \\
\text { employees is an important managerial skill. } \\
\text { Motivation is the set of forces that causes } \\
\text { people to choose certain behaviors from } \\
\text { among the many alternatives. }\end{array}$ & $\begin{array}{l}\text { Questionnaire on } \\
\text { employee motivation }\end{array}$ & $\begin{array}{l}\text { 1p: Less } \\
\text { than } 40 \% \\
\text { 2p: } 40-60 \% \\
\text { 3p: } 60-80 \% \\
\text { 4p: } 80-90 \% \\
\text { 5p: } 100 \%\end{array}$ \\
\hline 7 & Turnover & $\begin{array}{l}\text { In human resources context, turnover is the } \\
\text { act of replacing an employee with a new } \\
\text { employee }\end{array}$ & $\begin{array}{l}\text { Good turnover rate } \\
-1 \%-3 \%\end{array}$ & $\begin{array}{l}\text { 1p: More } \\
\text { than } 3 \% ; \\
\text { 2p:3\%; } \\
\text { 3p: } 2 \% ; \\
\text { 4p: } 1 \% ; \\
\text { 5p: Less } \\
\text { than } 1 \%\end{array}$ \\
\hline 8 & $\begin{array}{l}\text { Organiza- } \\
\text { tional climate }\end{array}$ & $\begin{array}{l}\text { Organizational climate (sometimes known } \\
\text { as Corporate Climate) is the process of } \\
\text { quantifying the "culture" of an organization, } \\
\text { and it precedes the notion of organizational } \\
\text { culture. It is a set of properties of the work } \\
\text { environment, perceived directly or indirectly } \\
\text { by the employees, that is assumed to be } \\
\text { a major force in influencing employee } \\
\text { behavior }\end{array}$ & $\begin{array}{l}\text { Questioning: «Socio- } \\
\text { psychological self- } \\
\text { assessment of the } \\
\text { group as a collective» } \\
\text { (SPSAGC) by } \\
\text { Gurevich (2010) }\end{array}$ & $\begin{array}{l}\text { 1p: Less } \\
\text { than } 40 \% \\
\text { 2p: } 40-60 \% \\
\text { 3p: } 60-80 \% \\
\text { 4p: } 80-90 \% \\
\text { 5p: } 100 \%\end{array}$ \\
\hline & \multicolumn{4}{|l|}{ Coordination } \\
\hline 9 & $\begin{array}{l}\text { Commu- } \\
\text { nication }\end{array}$ & $\begin{array}{l}\text { Communication helps managers to } \\
\text { perform their jobs and responsibilities. } \\
\text { Communication serves as a foundation } \\
\text { for planning. All the essential information } \\
\text { must be communicated to the managers. } \\
\text { Organizing also requires effective } \\
\text { communication with others about their } \\
\text { job task (Yuldasheva, 2012). Precisely, the } \\
\text { leaders as managers must communicate } \\
\text { effectively with their subordinates. }\end{array}$ & Questioning & $\begin{array}{l}\text { 1p: Not effective } \\
\text { (less than 40\%); } \\
\text { 2p: } 40-60 \% \\
\text { 3p: } 60-80 \% \\
\text { 4p: } 80-90 \% \\
\text { 5p: } 100 \%\end{array}$ \\
\hline 10 & $\begin{array}{l}\text { Decision- } \\
\text { making }\end{array}$ & $\begin{array}{l}\text { Making decisions in a company or } \\
\text { organization happens at all levels. Before } \\
\text { making any decision, the organization has } \\
\text { to identify exactly what the problem is. Not } \\
\text { identifying the problem could lead to an } \\
\text { erroneous decision (Petrikov et al., 2015). }\end{array}$ & Interview & $\begin{array}{l}\text { 1p: Not effective } \\
\text { (less than 40\%); } \\
\text { 2p: } 40-60 \% \\
\text { 3p: } 60-80 \% \\
\text { 4p: } 80-90 \% \\
\text { 5p: } 100 \%\end{array}$ \\
\hline & \multicolumn{4}{|l|}{ Controlling } \\
\hline 11 & $\begin{array}{l}\text { Marketing } \\
\text { control }\end{array}$ & $\begin{array}{l}\text { Marketing control is used by owners to } \\
\text { monitor and evaluate their current marketing } \\
\text { strategies to identify needed adjustments } \\
\text { and set guidelines for the future to achieve } \\
\text { marketing and business goals (Gribov, } \\
\text { 2015). }\end{array}$ & Expert methods & $\begin{array}{l}\text { 1p: Control is } \\
\text { not carried out; } \\
\text { 2p: } 10-20 \% \text {; } \\
\text { 3p: } 30-60 \% ; \\
\text { 4p: } 60-90 \% ; \\
\text { 5p: } 90-100 \%\end{array}$ \\
\hline
\end{tabular}

Source: Own source

As illustrated in the table 1, the internal marketing performance is analyzed using functions. As a marketing planning we understand a logical order of types of activity and procedures related to the goal setting, strategy selection, elaboration of measures to achieve them within a certain period of time based on assumptions about future prevailing conditions of the plan performance. Organization function task is to 
form the facility structure, provide it with all the things needed for the normal work. Management performance or lack of performance is substantially determined by the organizational structure. Moreover one of the most important tasks of the organization is to provide workplaces with technical aids. Technical aids of the management are a complex of technical aids used for collection, processing, representation and utilization of information by the management personnel.

Personnel analysis plays an important role. Personnel skill level, its attitude to work, creative potential, aiming for personal advancement and training, efficient communication and teamwork skills determine the future of every organization. Motivation here plays an important role. Motivation system is an efficient tool of the manager. To control the current situation the immediate manager should flexibly and promptly change motivation mechanisms adjusting to current conditions and tasks.

Coordination is a type of the management activity which is directed to the achievement of the concurrence in the work of all management links. Main coordination functions are communications and decision-making. Many employees receive information using only one communication channel. This can lead to insufficient understanding of information coming from the management. According to Balabanova (2001), availability of the feedback here plays an important role. This substantially improves the performance of the management information exchange. It is very important that any employee at any time has an opportunity to approach the manager to resolve production issues and to formulate tasks. This will give an opportunity to promptly execute works.

Moreover in the modern crisis conditions like never before requirements to the quality of management decisions are advanced because even the smallest mistake in choosing of the alternative can lead to negative consequences for the company. Control should be exercised at the facility over the satisfaction of objectives set. One of its main tasks is an early recognition of deviations from the program preset, budget control, quick actions related to the liquidation or prevention of deviations.

Careful analysis of these functions will give an opportunity to determine issues existing inside the department.

After the analysis of the internal performance we proceed to the second part of the method: the analysis of the external performance. We carry out the analysis of the external performance through developing of KPI (key performance index). They are developed specifically for the own company taking into consideration its activity specifics and various functional obligations of marketing specialists. Implementation of KPI gives an opportunity to measure and improve the work performance of the whole company and every specialist.

In our opinion the external performance of the marketing can be composed of the following main parameters which can be used by the facility adding its own indices (Table 2). 
Table 2 External marketing efficiency

\begin{tabular}{|c|c|c|c|c|}
\hline № & \begin{tabular}{|l} 
Evaluation \\
Parameters
\end{tabular} & Description & Evaluation & Scale \\
\hline 1 & Reporting & $\begin{array}{l}\text { Reporting structure refers to the authority } \\
\text { relationships in a company - who reports to } \\
\text { whom. With all the work and roles defined, } \\
\text { the owner can set up the organization's } \\
\text { vertical and horizontal aspects by } \\
\text { establishing reporting relationships. }\end{array}$ & $\begin{array}{l}\text { Surveillance. } \\
\text { Reports submitted } \\
\text { with a delay. }\end{array}$ & $\begin{array}{l}\text { 1p: Reports are not } \\
\text { provided; } \\
\text { 2p:Hardly ever; } \\
\text { 3p: Rare; } \\
\text { 4p: Often; } \\
\text { 5p: Always on time. }\end{array}$ \\
\hline 2 & $\begin{array}{l}\text { Competitive } \\
\text { monitoring }\end{array}$ & $\begin{array}{l}\text { The most prominent of these avenues } \\
\text { are the business competitors and their } \\
\text { various activities such as events, product } \\
\text { developments, product launches, and product } \\
\text { prices. Knowing what the competition will } \\
\text { do next puts the business in the position of } \\
\text { being able to plan how to counter it or how } \\
\text { to do better than the competition. }\end{array}$ & $\begin{array}{l}\text { New products; } \\
\text { sales; technology; } \\
\text { innovations. }\end{array}$ & $\begin{array}{l}\text { 1p: The analysis is } \\
\text { not carried out; } \\
\text { 2p:Hardly ever; } \\
\text { 3p: Rare; } \\
\text { 4p: Often; } \\
\text { 5p: Always. }\end{array}$ \\
\hline 3 & $\begin{array}{l}\text { Packaging } \\
\text { (design) }\end{array}$ & $\begin{array}{l}\text { Planning and controlling of the designer's } \\
\text { work. }\end{array}$ & $\begin{array}{l}\text { Packaging } \\
\text { corresponds to } \\
\text { the given theme } \\
\text { and the general } \\
\text { concept. Variations } \\
\text { in size, pattern, etc. } \\
\text { can be evaluated } \\
\text { by interviewing } \\
\text { the opinions of } \\
\text { consumers. }\end{array}$ & $\begin{array}{l}\text { 1p: Less than } 20 \% \text {; } \\
\text { 2p: } 30-40 \% \\
\text { 3p: } 40-60 \% \\
\text { 4p: } 60-90 \% \\
\text { 5p: } 90-100 \% .\end{array}$ \\
\hline 4 & $\begin{array}{l}\text { Marketing } \\
\text { research }\end{array}$ & $\begin{array}{l}\text { Marketing research is "the process or } \\
\text { set of processes that links the producers, } \\
\text { customers, and end users to the marketer } \\
\text { through information — information used to } \\
\text { identify and define marketing opportunities } \\
\text { and problems; generate, refine, and evaluate } \\
\text { marketing actions; monitor marketing } \\
\text { performance; and improve understanding of } \\
\text { marketing as a process. }\end{array}$ & $\begin{array}{l}\text { Number and } \\
\text { completeness; } \\
\text { their applicability } \\
\text { and relevance. } \\
\text { Marketing manager } \\
\text { interview }\end{array}$ & $\begin{array}{l}\text { 1p: Marketing } \\
\text { research is not } \\
\text { carried out. } \\
\text { 2p: Hardly ever; } \\
\text { 3p: Rare; } \\
\text { 4p: Often; } \\
\text { 5p: Always. }\end{array}$ \\
\hline 5 & Official site & $\begin{array}{l}\text { How to monitor the site; Whether } \\
\text { it functions; How often important } \\
\text { information is added. }\end{array}$ & $\begin{array}{l}\text { Frequency of } \\
\text { updates (more than } \\
\text { once at the end of } \\
\text { the month). Full } \\
\text { update volume (new } \\
\text { products, news are } \\
\text { displayed). } \\
\text { Problems in the work } \\
\text { of the site, errors. }\end{array}$ & $\begin{array}{l}\text { 1p: Work is not } \\
\text { conducted; } \\
\text { 2p: } 30-40 \% \\
\text { 3p: } 40-60 \% \\
\text { 4p: } 60-90 \% \\
\text { 5p: } 90-100 \%\end{array}$ \\
\hline 6 & Social network & $\begin{array}{l}\text { Developing a company's page in social } \\
\text { networks. }\end{array}$ & $\begin{array}{l}\text { Number of } \\
\text { subscribers (there } \\
\text { should be growth, } \\
\text { compared to the } \\
\text { previous month). Full } \\
\text { volume of updates } \\
\text { (new products, news, } \\
\text { interesting articles are } \\
\text { displayed). }\end{array}$ & $\begin{array}{l}\text { 1p: Work is not } \\
\text { conducted; } \\
\text { 2p: } 30-40 \% \\
\text { 3p: } 40-60 \% \\
\text { 4p: } 60-90 \% \\
\text { 5p: } 90-100 \%\end{array}$ \\
\hline
\end{tabular}




\begin{tabular}{|c|c|c|c|c|}
\hline 7 & Advertising & $\begin{array}{l}\text { Advertising is an audio or visual form of } \\
\text { marketing communication that employs } \\
\text { an openly sponsored, nonpersonal } \\
\text { message to promote or sell a product, } \\
\text { service or idea. }\end{array}$ & Correlation analysis & $\begin{array}{l}\text { 1p: Less than } 0,2 \% \\
\text { 2p: } 0,2-0,3 \% \\
\text { 3p: } 0,3-0,6 \% \\
\text { 4p: } 0,6-0,8 \% \\
\text { 5p: } 0,8-1 \%\end{array}$ \\
\hline 8 & Costs & $\begin{array}{l}\text { A marketing budget typically covers costs } \\
\text { for advertising, promotion and public } \\
\text { relations. Each amount varies based } \\
\text { on the size of the business, its annual } \\
\text { sales and how much the competition is } \\
\text { advertising (Shadrina, 2016). Depending } \\
\text { on the industry, marketing budgets can } \\
\text { range from as low as } 1 \% \text { of sales to over } \\
30 \% \text {. New companies may spend as } \\
\text { much as } 50 \% \text { of sales for introductory } \\
\text { marketing programs in the first year. }\end{array}$ & $\begin{array}{l}\text { Marketing } \\
\text { costs within the } \\
\text { established budget }\end{array}$ & $\begin{array}{l}\text { 1p: The costs } \\
\text { significantly exceed } \\
\text { the established } \\
\text { budget; } \\
\text { 2p: Large } \\
\text { deviations; } \\
\text { 3p: Small deviations } \\
\text { from the budget; } \\
\text { 4p: Within budget; } \\
\text { 5p: There are } \\
\text { reserves for the next } \\
\text { period. }\end{array}$ \\
\hline 9 & Event marketing & $\begin{array}{l}\text { Event marketing is a promotional } \\
\text { strategy that involves face-to-face contact } \\
\text { between companies and their customers } \\
\text { at special events like concerts, fairs, } \\
\text { and sporting events. Brands use event } \\
\text { marketing entertainment (like shows, } \\
\text { contests, or parties) to reach consumers } \\
\text { through direct hand-to-hand sampling } \\
\text { or interactive displays. The practice } \\
\text { works because it engages consumers } \\
\text { while they're in a willing, participatory } \\
\text { position. }\end{array}$ & $\begin{array}{l}\text { The number of } \\
\text { events carried } \\
\text { out and their } \\
\text { significance. } \\
\text { Correlation analysis }\end{array}$ & $\begin{array}{l}\text { 1p: } 0,2 \% \\
\text { 2p: } 0,2-0,3 \% \\
\text { 3p: } 0,3-0,6 \% \\
\text { 4p: } 0,6-0,8 \% \\
\text { 5p: } 0,8-1 \%\end{array}$ \\
\hline 10 & $\begin{array}{l}\text { Product } \\
\text { Management }\end{array}$ & $\begin{array}{l}\text { Product management is an organizational } \\
\text { lifecycle function within a company } \\
\text { dealing with the planning, forecasting, } \\
\text { and production, or marketing of a product } \\
\text { or products at all stages of the product } \\
\text { lifecycle. }\end{array}$ & $\begin{array}{l}\text { Analysis of the } \\
\text { demand: } \\
\text { Identification of } \\
\text { unsatisfactory } \\
\text { product parameters; } \\
\text { communication } \\
\text { with consumers; } \\
\text { Sales forecasting }\end{array}$ & $\begin{array}{l}\text { 1p: Product } \\
\text { management is not } \\
\text { carried out; } \\
\text { 2p: Hardly ever; } \\
\text { 3p: Rare; } \\
\text { 4p: Often; } \\
\text { 5p: Always. }\end{array}$ \\
\hline
\end{tabular}

Source: Own source

As can be seen from the above, the measure of marketing work results using KPI system will give to specialists an opportunity to have a clear vision about objectives of their work and those benefits which they can get. Indices should be periodically revised because of the possible loss of performance and the impact on the employee motivation. It is necessary to keep KPI meeting objectives of the company at every stage of its development. Result of the examination of the cumulative marketing performance is to reduce the informational uncertainty in the sphere of forming and using marketing resources and results to the level giving an opportunity to make managerial decisions reasonable in all directions of the marketing activity. In unstable conditions and constant changing of the external environment we consider that it is necessary to assess risks. In marketing there is a fair principle: who does not risk that one does not win. However the marketing risk is a possibility to be commercially defeated in the market or not to meet strategic goals set, to incur economic and financial losses, lose part of resource and etc. To 
recognize risks in the unstable marketing conditions environment where there is no information about the possible occurrence of risk events, companies should quickly react to any changes and create a new strategy which will give an opportunity to the facility to successfully operate. If the facility successfully implements the policy chosen making decisions taking into consideration risk factors, it will be possible to speak about the marketing activity performance and about the improving of the competitiveness of the facility. That's why with help of the expert method we suggest detaching the risk level which will be measured when making marketing decisions. Expert measure methods are a part of the broad sphere of making decisions. Expert measuring is a procedure of measuring the issue based on the opinion of specialists (experts) to further make decisions by themselves. At first it is necessary to detach risks which can be found in the company analyzed based on both internal and external indices. Approximate list is given in the Table 3.

Table 3 Marketing risks

\begin{tabular}{|c|c|c|}
\hline № & Efficiency parameter & Risks \\
\hline & \multicolumn{2}{|r|}{ Internal efficiency } \\
\hline 1 & Planning & $\begin{array}{l}\text { Incorrect formulation of the task; } \\
\text { Goal unattainability }\end{array}$ \\
\hline 2 & Organizing & $\begin{array}{l}\text { Inefficient workflows; } \\
\text { Duplication of functions }\end{array}$ \\
\hline 3 & Coordinating & Wrong decision-making \\
\hline 4 & Motivating & $\begin{array}{l}\text { Employees leave an organization; } \\
\text { Labour productivity fall }\end{array}$ \\
\hline 5 & Controlling & Inconsistency between the plan and the fact \\
\hline 6 & Reporting & $\begin{array}{l}\text { Wrong interpretation of the results; } \\
\text { Wrong decision }\end{array}$ \\
\hline 7 & Competitive analysis & $\begin{array}{l}\text { New competitors; } \\
\text { Entering the food market of a multidisciplinary (diversified) firm } \\
\text { from other industries; } \\
\text { Expansion to the local market by foreign exporters }\end{array}$ \\
\hline 8 & Marketing research & Risk of incorrect organization and results \\
\hline 9 & Advertising & $\begin{array}{l}\text { Advertising inefficiency; } \\
\text { Entering into contractual relations with incompetent or insolvent } \\
\text { partners }\end{array}$ \\
\hline 10 & Costs & $\begin{array}{l}\text { Risk of budget overspending; } \\
\text { Inefficient use of funds }\end{array}$ \\
\hline 11 & Event marketing & Event inefficiency \\
\hline 12 & Product management & $\begin{array}{l}\text { Pricing errors; } \\
\text { Risk of unsuccessful organization of the sales network and the } \\
\text { system of promotion }\end{array}$ \\
\hline 13 & Catalog development & Risk of incorrectly displayed information \\
\hline 14 & Work with corporate shops & Wrong chosen strategy \\
\hline 15 & Trade mark registry work & Lawsuits \\
\hline 16 & Trial Marketing & $\begin{array}{l}\text { The expenditure of large funds on goods that may not fall into } \\
\text { mass production }\end{array}$ \\
\hline
\end{tabular}

Source: Own source 
Risks detached should be put in order of the most important to the least important ones. Ranging gives an opportunity to choose the most essential factor from ones of the combination examined.

Further we make the table where experts' opinions are reflected (Table 4):

Table 4 Ranking criteria

\begin{tabular}{|c|c|c|c|c|c|c|c|c|c|c|c|c|c|c|c|c|}
\hline \multirow{2}{*}{ Criteria } & \multicolumn{13}{|c|}{ Experts } & \multirow[t]{2}{*}{$\mathrm{E}$} & \multirow[t]{2}{*}{ Deviations } & \multirow[t]{2}{*}{$\Delta^{2}$} \\
\hline & 1 & 2 & 3 & 4 & 5 & 6 & 7 & 8 & 9 & 10 & 11 & 12 & 13 & & & \\
\hline \multicolumn{17}{|c|}{ Grades } \\
\hline \multicolumn{17}{|l|}{ K 1} \\
\hline \multicolumn{17}{|l|}{ K 2} \\
\hline \multicolumn{17}{|l|}{$\ldots$} \\
\hline \multicolumn{17}{|l|}{$\mathrm{N}$} \\
\hline Summary & & & & & & & & & & & & & & & & $\mathrm{S}$ \\
\hline
\end{tabular}

Source: Own source

Next, we determine the sum of the ranks of each factor-the sum by lines and the deviation of the sum of ranks using the formula:

$$
\Delta^{a}=\frac{\sum_{k=1}^{K} \Delta k}{k}
$$

Then, we determine the deviation of the sum of the ranks of each factor from the average sum of ranks:

$$
\Delta_{k}^{\prime}=\Delta_{k}-\Delta^{a}
$$

We used Kendall's coefficient of concordance (aka Kendall's $W$ ) to measure agreement between raters. It indicates the degree of association of ordinal assessments made by multiple appraisers when assessing the same samples. This coefficient is commonly used in attribute analysis. The formula is:

$$
W=\frac{12 * S}{m^{2}\left(k^{3}-k\right)}
$$

where

$k$ - number of factors;

$m$ - number of experts.

The concordance coefficient can vary from 0 to 1 . If it is significantly different from zero ( $\mathrm{W} \geq 0,5)$, then we can assume that there is some agreement between the opinions.

At the final stage, we propose to analyze the results and make recommendations. 


\section{Conculsion}

The result of this research - usage the proposed method - have informative character (to clarify the situation, to confirm or disprove assumptions, or to collect information) and a recommendatory character as well since it can be used as a formalized base for the adoption of managerial and marketing decisions.

The direction of further research is seen in the approbation of the developed methodology in the modern enterprise.

\section{References}

Ambler, T. (2000). Marketing and the Bottom Line: The New Metrics of Corporate Wealth. London, UK: Financial Times / Prentice-Hall.

Ambler, T., Kokkinaki, F. (1997). Measures of marketing success. Journal of Marketing Management, 5(13), pp. 665-78.

Ambler, T., Kokkinaki, F., Puntoni, S., Riley, D. (2001). Assessing market performance: The current state of metrics. London, UK: Centre for Marketing Working Paper.

Appiah-Adu, K. (1998). Marketing activities and business performance: evidence from foreign and domestic manufacturing firms in liberalized developing economy. Marketing Intelligence \& Planning, 16(7), 436-442.

Appiah-Adu, K., Fyall, A., Singh, S. (2001). Marketing effectiveness and business performance in the financial services industrial. Journal of Services Marketing, 15(1), 18-34.

Assel, G. (1999). Marketing: principles and strategy: A textbook for high schools. Moscow: INFRA-M.

Balabanova, L.V. (2001). Marketing. Moscow: Scientific publication / Donetsk: DonGUET.

Besfamilnaya, S.V. and Rozhkov, A.A. (2002). Organization of monitoring of system of reproduction of working places created by programme of local development in cool industry regions. Uhol, 3, 50-56.

Eusebio, R., Andreu, J.L., Belbeze, M.P.L. (2006). Measure of marketing performance; a comparative study from Spain. International Journal of Contemporary Hospitality Management, 18(2), 145-155.

Gribov, V.D. (2015). Management: a study guide. Moscow: KNORUS.

Gurevich, K.M. (2010). Psychological diagnostics: a textbook for universities. St. Petersburg: Peter.

Doyle, P., Wong, V. (1998). Marketing and competitive performance: an empirical study. European Journal of Marketing, 32(516), 514-535.

Kaplan, R.S., Norton, D.P. (2001). The Strategy-focused organization: how Balanced Scorecard companies thrive in the new business environment. Harvard, MA: Harvard Business School Publishing Corporation. 
Moiseeva, N.K., Konysheva, M.V. (2002). Marketing management: theory, practice, information technology. Moscow: Finansy i statistika Publ.

Petrikov, A.M., Isaeva, E.I., Ovsyannikova, M.A. (2015). Methods for valuation of intangible assets. All for the accountant, 3, 15-27.

Shadrina, G.V. (2016). Economic analysis. Theory and practice: a textbook for bachelors. Moscow: Izdatelstvo Yurayt.

Starov, S.A., Alkanova, O.N. (2010). Evaluation of branding efficiency in modern marketing theory (part 2). Brand management, 5, 2-20.

Ward, K. (2004). Marketing Finance: Turning Marketing Strategies into Share-holder Value. New York: Taylor \& Francis.

Woodburn, D. (2004). Engaging marketing performance measurement, Measuring Business Excellence, the Journal of Organizational Performance Management, $8(4), 63-72$.

Yuldasheva, O.U. (2012). Personalization of marketing communications - a reference point for adapting a marketing mix to the requirements of consumers in the context of informatization of society. Marketing communications, 4, 204-212. 